\title{
First record of Platyceps rhodorachis (Jan in de Filippi, 1865) from the Alay Mountains, southern Kyrgyzstan
}

\author{
Daniel Jablonski ${ }^{1}$, Andrei Bragin ${ }^{2}$ \\ 1 Department of Zoology, Comenius University in Bratislava, Ilkovičova 6, Mlynská dolina, Bratislava, Slovakia \\ 2 Faculty of Biology, Department of Vertebrate Zoology, Moscow State University, Moscow, Russia \\ http://zoobank.org/EC627D22-208C-4EB0-9984-4B32C95B04AE \\ Corresponding author: Daniel Jablonski (daniel.jablonski@balcanica.cz)
}

Academic editor: Günter Gollmann • Received 22 December 2018 • Accepted 11 March 2019 • Published 13 May 2019

\begin{abstract}
We report recent observations of Platyceps rhodorachis (Jan in de Filippi, 1865) from Kyrgyzstan and the first species record from the Alay Mountains. It represents an important range extension in the Central Asiatic distribution of the species.
\end{abstract}

\section{Key Words}

Central Asia, Colubridae, Coluber, range extension, new records, distribution

Kyrgyzstan is a Central Asiatic country where basic zoological research has been conducted mostly during the Soviet Era (Chernov 1959; Bannikov et al. 1977). Although its territory is part of the biodiversity hotspot of the Mountains of Central Asia, distribution of particular species is poorly known and data are scattered in different, mainly Russian-written sources. The recently described species Gloydius rickmersi Wagner, Tiutenko, Borkin \& Simonov, 2016 is a good example of how the territory of the country is herpetologically important. Wagner et al. (2016) especially highlighted the importance of the Alay-Pamir region as a territory where herpetological knowledge is limited and based only on several zoological expeditions conducted in the first half of $20^{\text {th }}$ century. Despite recent investigations (Wagner et al. 2016), herpetological knowledge remains poor in the Alay Mountains.

Here, we present the first documented record of Platyceps rhodorachis Jan in de Filippi, 1865 from the Alay Mts. that represents an important range extension in the Central Asiatic distribution of the species. This polytypic species has a large area of distribution ranging from NE Iraq to Kyrgyzstan and probably westernmost Nepal (Schätti et al. 2014), where it inhabits a variety of habitats.
To date, overall six records of the species are known from Kyrgyzstan, two from the west part of the Chuy Valley (Bishkek area), one probably from Talas Alatau and three following the Naryn River Valley up to the Fergana Valley (Table 1, Fig. 1; Schätti et al. 2014 and literature therein).

Our new record comes from Osh Province, southern Kyrgyzstan (Vidana village located at the canyon of Ak-Buura River; 40¹2'47.7"N, 7258'18.9"E; $1465 \mathrm{~m}$ a.s.1.; loc. 8, Fig. 1). The adult male (Figs 2A and B) was recorded on 18 May 2018, around $1700 \mathrm{~h}$ local time. The individual was hidden under a large stone located in a rocky habitat with scattered, bushy vegetation near to the river (Fig. 2C). This is the first record in this region and province and is now the most southern record of the species in the country, being located approximately $130 \mathrm{~km}$ in a straightline from the closest records in northern parts of the Fergana Valley (Jeremcenko et al. 1992; locs. 5 and 6, Fig. 1). Concurrently, this record represents one of the eastern borders of the species distribution in Kyrgyzstan and Central Asia. During the same two-weeks long field research in Kyrgyzstan in May 2018, we recorded another individual of $P$. rhodorachis near to Toktogul reservoir, located on the Naryn River (loc. 7, Fig. 1). This record comes from Imeni 
Table 1. An updated distribution records of Platyceps rhodorachis in Kyrgyzstan.

\begin{tabular}{|c|c|c|c|c|}
\hline $\begin{array}{l}\text { Number on } \\
\text { the map }\end{array}$ & Reference & Origin & WGA coordinates & Comments \\
\hline 1 & Chernov (1959) & Uzun Akhmat Valley & ca. $41^{\circ} 50^{\prime} \mathrm{N}, 72^{\circ} 30^{\prime} \mathrm{E}$ & MMGU 1171 \\
\hline 2 & Chernov (1959) & "Umgebung von Frunse" [Bishkek area] & unspecified record & MTD 13640 \\
\hline 3 & Bannikov et al. (1977: map 115) & Bishkek area & ca. $42^{\circ} 52^{\prime} \mathrm{N}, 74^{\circ} 35^{\prime} \mathrm{E}$ & unspecified record \\
\hline 4 & Kolbinczev and Brushko (1986) & "Talasskogo Alatau" [Talas Alatau] & - & Kazakh border area \\
\hline 5 & Jeremcenko et al. (1992) & $\begin{array}{c}\text { okr. g. Tash-Kumyr, Ferganskaja dolina } \\
\text { [Fergana Valley] }\end{array}$ & ca. $41^{\circ} 21^{\prime} \mathrm{N}, 72^{\circ} 13^{\prime} \mathrm{E}$ & ANRKyr 4012 \\
\hline 6 & Jeremcenko et al. (1992) & $\begin{array}{l}\text { okr. g. "Majli-Saj" Mayluu-Suu, Noo- } \\
\text { kenskij B. Jalal-Abad Obl. }\end{array}$ & ca. $41^{\circ} 17^{\prime} \mathrm{N}, 72^{\circ} 28^{\prime} \mathrm{E}$ & ANRKyr 4186 \\
\hline 7 & This study & $\begin{array}{c}\text { Imeni Chkalova, between Uch-Terek and } \\
\text { Karakol, Jalal-Abad Province }\end{array}$ & $41^{\circ} 46^{\prime} 05.6^{\prime \prime} \mathrm{N}, 72^{\circ} 57^{\prime} 14.1^{\prime \prime} \mathrm{E}$ & Not collected \\
\hline 8 & This study & Vidana, Nookat District, Osh Province & $40^{\circ} 12^{\prime} 47.7^{\prime \prime} \mathrm{N}, 72^{\circ} 58^{\prime} 18.9^{\prime \prime} \mathrm{E}$ & Not collected \\
\hline
\end{tabular}

Abbreviations: MMGU - Moskovskij Gosudarstvennyj Universitet (MMGU, Moscow State University, 'M. V. Lomonosov'); MTD - Staatliches Museum für Tierkunde, Dresden; ANRKyr - Akademij nauk Respubliki Kyrgyzstan (Academy of Sciences of Kyrgyzstan Republic).

Chkalova village, between Uch-Terek and Karakol villag-

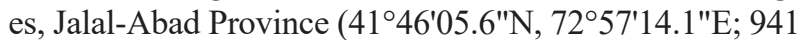
$\mathrm{m}$ a.s.1.) and roughly corresponds with the first published record of the species in Kyrgyzstan (Chernov 1959). The adult female was found on 16 May 2018 around noon under a stone on the grassy habitat (Figs 2D-F).

The range of $P$. rhodorachis in Kyrgyzstan has a peripheral character (see distribution review in Schätti et al. 2014 and Fig. 1) and the species probably extends into Kyrgyzstan from steppe or lowland regions of its western continuous range in Kazakhstan (Chuy and Talas river valleys), Uzbekistan and Tajikistan (Fergana Valley and valley of Naryn River). Schätti et al. (2014) expected its occurrence in Batken and Osh Provinces in southern Kyrgyzstan east to the Jalal-Abad region and it is confirmed by our record. Several other species of reptiles have a similar distribution range in Kyrgyzstan (e.g. Testudo horsfieldi, Pseudopus apodus; Sindaco \& Jeremcenko 2008). Verification of the presence of $P$. rhodorachis through the Talas River Valley, beyond western Chuy Valley and eastern territories of the Naryn River Valley in Central Kyrgyzstan is, however, another challenge.

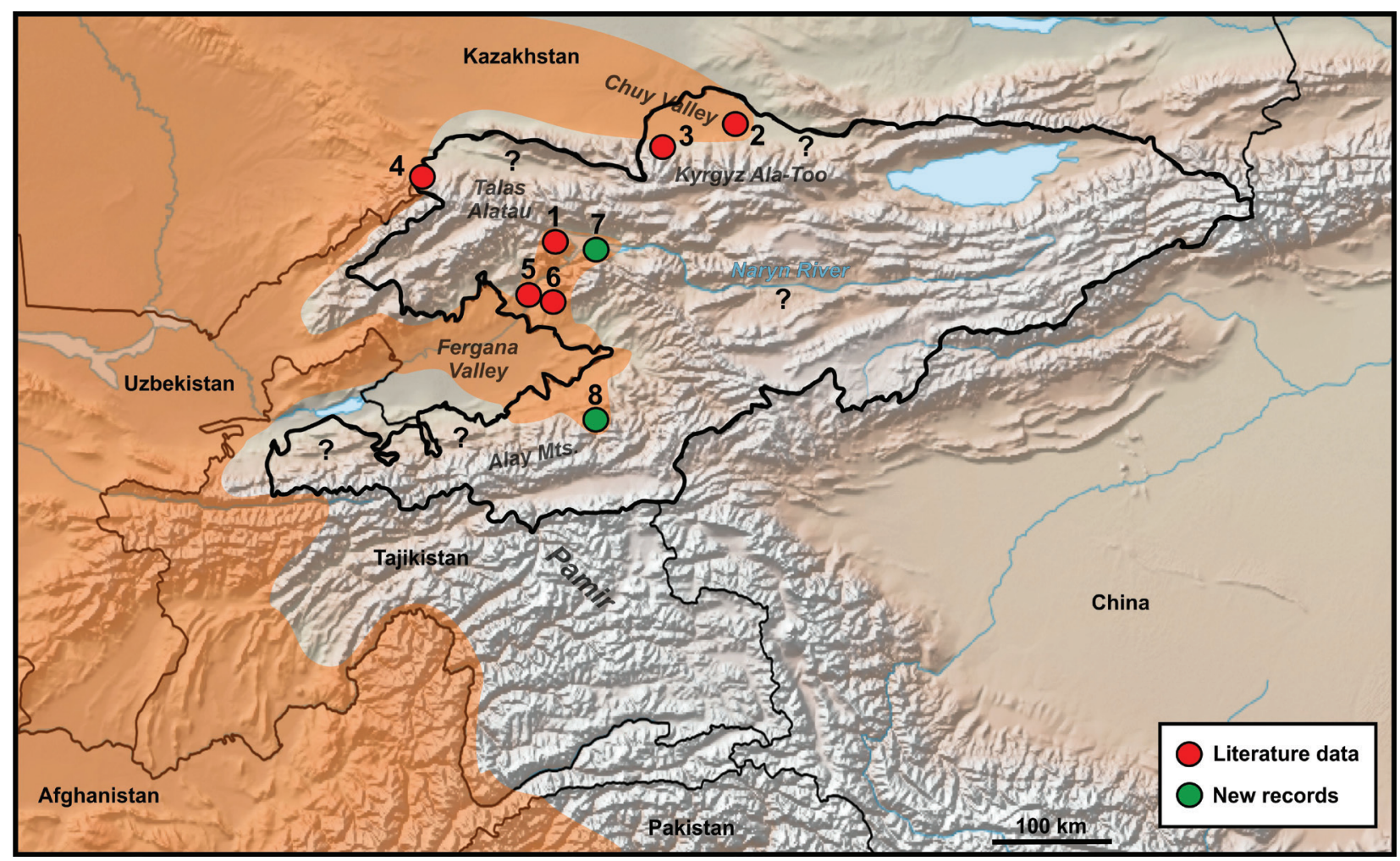

Figure 1. Distribution records of Platyceps rhodorachis in Kyrgyzstan. Numbers of records correspond with Table 1. The question mark suggests possible occurrence of the species in Kyrgyzstan (see main text). The known distribution range of the species in Central Asia is highlighted in orange following data of Schätti et al. (2014). 

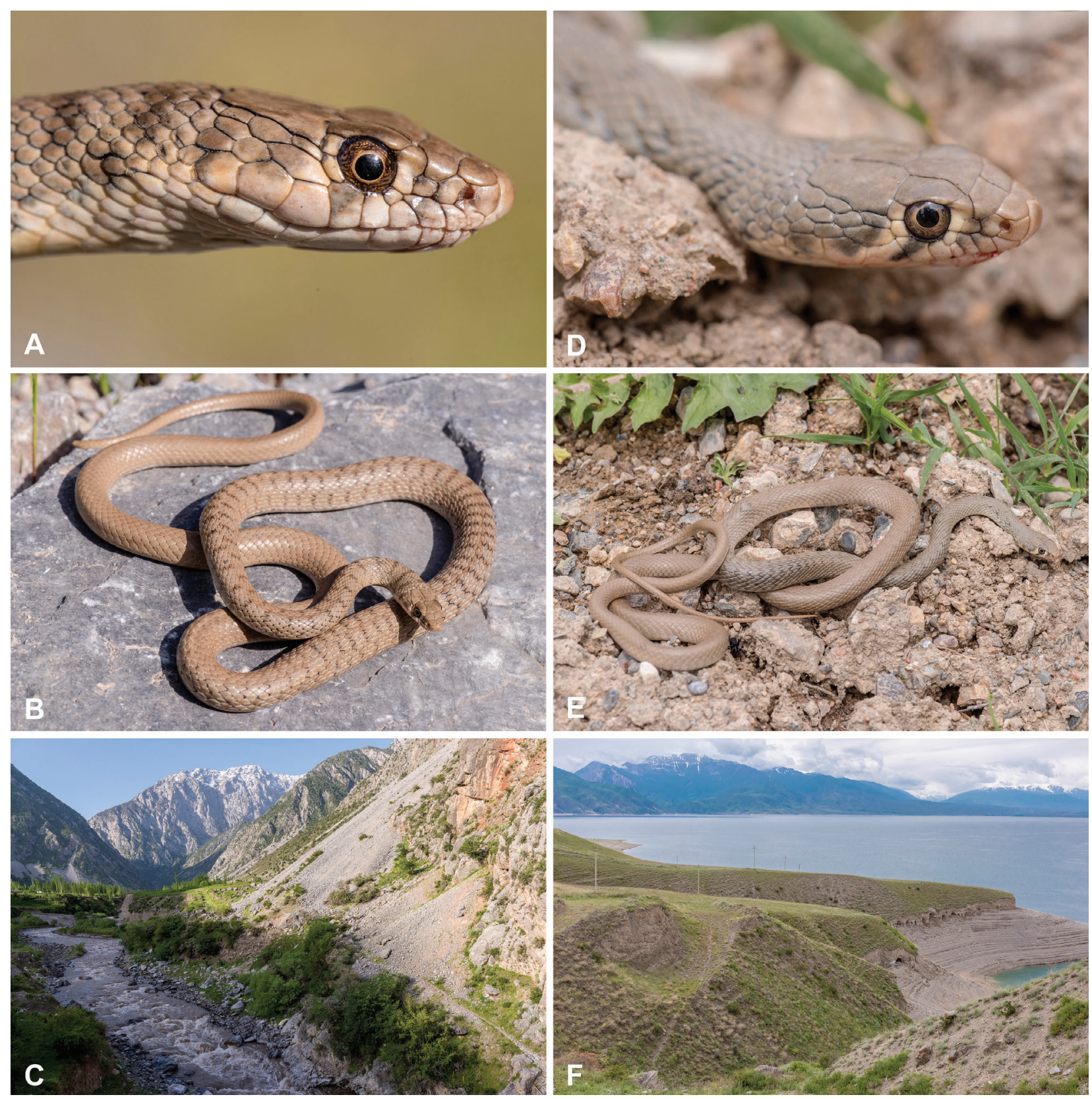

Figure 2. Platyceps rhodorachis from Kyrgyzstan: A-C. adult male from the locality Vidana, Osh Province and its habitat; D-F. adult female from Imeni Chkalova, Jalal-Abad Province and its habitat around Toktogul reservoir.

\section{Acknowledgements}

We thank Beat Schätti and Philipp Wagner for their important suggestions to our work. This study was supported by the Slovak Research and Development Agency under the contract no. APVV-15-0147.

\section{References}

Bannikov AG, Darevskij IS, Iszczenko BG, Rustamov AK, Szczerbak NN (1977) Opredelitel zemnovodnykh i presmykajuszczikhsja fauny SSSR [Determination guide to the amphibians and reptiles of the fauna of the USSR]. Prosveszczenje, Moscow, 414 pp.
Chernov SA (1959) Fauna Tadzhikskoj SSR. Tom XVIII [Trudy XCVIII]. Presmykajuszcziesja [Fauna of Tajik SSR. Vol. XVIII (Publication XCVIII). Reptiles]. Akademija Nauk Tadzhikskoj SSR, Stalinabad [Dushanbe], 204 pp.

Jeremcenko VK, Panfilov AM, Czarinenko EI (1992) Katalog kollekczij zemnovodnykh i presmykajuszczikhsja Zoologicheskogo muzeja Instituta biologij Akademij nauk Respubliki Kyrgyzstan [Catalogue of the collection of amphibians and reptiles in the Zoological Museum of the Institute of Biology of the Academy of Sciences of Kyrgyzstan Republic]. In: Jeremcenko VK, Panfilov AM, Czarinenko EI (Eds.) Konspekt issledovanij po czitogenetike i sistematike nekotorykh Aziatskikh vidov. Scincidae i Lacertidae [Overview of cytogenetic and systematic investigations on some Asiatic species. Scincidae and Lacertidae]. Ilim, Bishkek, 92-176. 
Kolbinczev VG, Brushko ZK (1986) K rasprostraneniju krasnopolosogo poloza v Kazakhstane [On the distribution of \{Platyceps $r$. rhodorachis $\}$ in Kazakhstan]. In: Gvozdev EV (Ed.) Rare species of animals of Kazakhstan (Materials to the second edition of the Red Data Book of Kazakh SSR). Nauka, Alma-Ata, 178-180.

Schätti B, Tillack F, Kucharzewski C (2014) Platyceps rhodorachis (Jan, 1863) - a study of the racer genus Platyceps Blyth, 1860 east of the Tigris (Reptilia: Squamata: Colubridae). Vertebrate Zoology 64: $297-405$.
Sindaco R, Jeremcenko VK (2008) The Reptiles of the Western Palearctic. Annotated Checklist and Distributional Atlas of the Turtles, Crocodiles, Amphisbaenians and Lizards of Europe, North Africa, Middle East and Central Asia. Monografie della Societas Herpetologica Italica, $579 \mathrm{pp}$.

Wagner P, Tiutenko A, Mazepa G, Borkin LJ, Simonov E (2016) Alai! Alai! - a new species of the Gloydius halys (Pallas, 1776) complex (Viperidae, Crotalinae), including a brief review of the complex. Amphibia-Reptilia 37: 15-31. https://doi.org/10.1163/15685381-00003026 